\title{
Sigi Kelengkapan Media Pembelajaran Geografi pada SMA Negeri di Palangka Raya
}

\author{
Eri Puspita Dewi, Krisma Natalia, Teguh Pribadi
}

Masuk: 09042018 / Diterima: 28062018 / Dipublikasi: 30062018

(C) 2018 Fakultas Hukum dan IImu Sosial UNDIKSHA dan IGI

\begin{abstract}
This study was conducted to analyze the geographical learning media completeness (GLMC). Eight public senior high schools (PSHS) were surveyed from August to September 2015. GLMC questionnaire used to explore those data. Descriptive statistics used to reveal school characteristics and GLMC. Cross-tabulation with chi-square analysis applied to measure not only school accreditation (SA) but also school quality (SQ) with GLMC. GLMC at PSHA in Palangka Raya were less full criteria. Software, laboratory equipment, mock-ups, visual-aids, and specimens were some samples of GLMC rarely found at PSHA in Palangka Raya. SA was not correlated with GLMC $(\chi 2=8,533 ; C=0,718 ; d f=4 ; p=0,074)$ so it was $S C(\chi 2=2,000 ; C=0,447 ; d f=2 ; p=0,368)$. Nevertheless, PSHA in Palangka Raya had higher SA and SQ indicated qualified GLMC. Apply school facilities and infrastructures management enhanced the quality of the geographical learning media (GLM). Teachers should optimize GLM at school by increasing their information technology literacy and skill.
\end{abstract}

Keywords: Geographical Learning Media; Public Senior High Schoo; School Accreditation; School Quality

Abstrak Penelitian ini bertujuan menganalisis kelengkapan media pembelajaran geografi (KMPG). Delapan SMA negeri (SMAN) di Kota Palangka Raya dipilih untuk disigi tentang KMPG dari Agustus September 2015. Angket tentang KMPG digunakan untuk mengekplorasi data tersebut. Statistika deskriptif digunakan untuk mengungkap karakteristik sekolah dan KMPG. Analisis tabulasi silang digunakan untuk mengukur hubungan masing-masing peubah. KMPG di SMAN di Kota Palangka Raya secara umum menunjukan kriteria kurang lengkap. Perangkat lunak, peralatan laboratorioum, maket, peraga, dan spesimen jarang dimiliki oleh SMAN di Palangka Raya. Akreditasi sekolah tidak menunjukan hubungan yang nyata dengan KMPG $(\chi 2=8,533 ; C=0,718 ; d f=4 ; p=0,074)$, begitu juga dengan kualitas sekolah $\left(\chi^{2}=2,000 ; \quad C=0,447 ; d f=2 ; p=0,368\right)$. Namun, SMAN dengan akreditasi dan kualitas lebih baik memiliki KMPG yang lebih bagus. Peningkatan kualitas manajemen media pembelajaran geografi (MPG) perlu diperbaiki. Disamping itu, guru-guru dapat mendayagunakan MPG yang ada dengan meningkatkan literasi dan keterampilan teknologi informasi.

Kata kunci : , Media Pembelajaran Geografi; SMA Negeri; Akreditasi Sekolah, Kualitas Sekolah

\section{Pendahuluan}

Media pembelajaran geografi (MPG) adalah segala bentuk sesuatu baik barang asli maupun hasil tiruan, manipulasi, modifikasi dan simplikasi yang dapat

\footnotetext{
Eri Puspita Dewi

Program Studi Pendidikan Geografi, FKIP Universitas PGRI Palangka Raya.

Krisma Natalia

Program Studi Pendidikan Sejarah, FKIP Universitas PGRI Palangka Raya

Teguh Pribadi

Institut Penyelidikan Pembangunan Berkelanjutan (Indek) PGRI Palangka Raya

Palangka Raya

eripuspita@rocketmail.com, krisma.natalia@yahoo.com, tgpribadi@gmail.com
}

digunakan sebagai perantara dalam proses pembelajaran geografi agar penyampaian materi ajar dari suatu topik pembelajaran geografi dapat diterima dengan mudah dan diserap oleh peserta didik sehingga dapat meningkatkan efektivitas dan efisiensi pencapaian tujuan pembelajaran geografi sesuai dengan rancangan skenario mengajar pendidik (Widodo, dalam Prasetya, 2014). Pembelajaran sebagai suatu proses pengembangan pengetahuan, keterampilan, pengembangan tingkah laku melibatkan interaksi individu, fasilitasfasilitas fisik, psikologis, metode 
pembelajaran, media pembelajaran, dan teknologi. Dengan demikian belajar adalah proses yang melibatkan proses seleksi, pengaturan, penyampaian pesan yang pantas kepada lingkungan dan bagaimana cara pebelajar berinteraksi dengan informasi tersebut. Maka pemilihan media sebaiknya tidak dilepaskan dalam konteks bahwa media merupakan komponen dari sistem pembelajaran secara utuh. Dengan demikian faktor-faktor seperti karakteristik siswa, strategi dan metode pembelajaran, saran dan prasarana, alokasi waktu, dan sumber belajar, serta prosedur penilaian juga perlu dipertimbangkan (Prasetya, 2014).

Materi pembelajaran geografi di sekolah memerlukan media pembelajaran yang lebih banyak dan variatif untuk meningkatkan efektivitas dan efisiensi penyampaian tujuan pembelajaran geografi. Materi-materi pembelajaran geografi seperti gejala-gejala geosfera dan proses-proses alamiah adalah situasi nyata yang tidak selalu dapat disediakan oleh guru baik di kelas maupun di lingkungannya. Oleh karena itu MPG harus dapat memberikan gambaran atau situasi nyata atau contoh situasi buatan dalam sajian yang representatif. Konsep materi pembelajaraan geografi yang luas (seperti: gunung berapi, gempa bumi, iklim, laut, sungai, dan danau) dapat divisualisasi dalam miniatur, model, maupun gambar yang disajikan secara visual, audio atau bahkan audio-visual (Prasetya, 2014). Selain itu MPG yang digunakan juga harus konstekstual, interaktif, dan menarik (Prasetya, 2014).

Beberapa penelitian menunjukan bahwa pemanfaatan media pembelajaran dapat meningkatkan hasil belajar geografi. Pemanfaatan media pembelajaran ebook \& textbook (Sufia \& Kurniawati, 2013), media pembelajaran interaktif berbasis perangkat lunak Macaromedia Flash Professional 8.0 (Siagian \& Lingin, 2012), kartu hidrologi (Shofifah \& Sigit, 2013) mampu meningkatkan hasil belajar geografi di SMA. Lebih lanjut, pemanfaatan multimedia yang dipadukan dengan metode pembelajaran inkuiri terbimbing terbukti meningkatkan efektivitas pembelajaran, minat dan pemahaman siswa (Wahyudin, Sutikno, \& Isa, 2010). Selain itu, pemanfaatan media pembelajaran berbasis perangkat lunak Power Point dapat meningkatkan aktivitas belajar, dan sikap siswa hampir $20 \%$ dari penilaian awal (Sidi \& Sudrajat, 2014).

Namun demikian, pemanfaatan media pembelajaran yang dimiliki cenderung beragam belum dimanfaatkan secara optimal. Setianingsih, Banowati, \& Santoso (2013) melakuakn sigi di sepuluh SMA Negeri (SMAN) di Kabupaten Jepara menunjukan bahwa hanya tiga SMAN yang memiliki media pembelajaran yang sangat lengkap dan lima SMAN yang dimasukkan dalam kategori lengkap. Berdasarkan sigi yang dilakukan media pembelajaran yang tersedia dalam kondisi baik dan tepat penggunaanya. Akan tetapi, kelengkapan media pembelajaran yang tersedia tidak didukung dengan jumlah yang memadai untuk mendukung proses belajar mengajar. Begitu juga dengan hasil penelitian Awaludin (2007) yang menyebutkan bahwa kelengkapan MPG di SMAN di Kabupaten Banjarnegara kurang memadai. SMAN yang memiliki media pembelajaran yang lengkap tidak lebih dari 40\%.

Berdasarkan fakta tersebut, apakah SMAN di Kota Palangka Raya memiliki MPG yang lengkap? Sam, pai saat ini, sigi tentang kelengkapan media pembelajaran geografi (KMPG) yang dimiliki oleh SMAN di Palangka Raya belum dilakukan. Oleh karena itu, penelitian ini bertujuan mendeksripsikan dan mengevaluasi KMPG yang dimiliki oleh SMAN di Palangka Raya. 


\section{Metode}

Delapan SMAN dari 10 SMAN di Kota Palangka Raya dipilih sebagai contoh secara sengaja (convenince sampling) dengan pertimbangan kualitas pembelajaran, manajemen sekolah, dan aksesibilitas. Sigi dilakukan dari Bulan Agustus sampai Bulan September 2015. Angket yang digunakan dalam penelitian berdasarkan angket yang disusun oleh Awaludin (2007) dengan beberapa perubahan. Teknik dokumentasi dengan menggunakan alat bantu mekanis berupa kamera digital dan wawancara terstruktur dilakukan untuk melengkapi data primer yang dikumpulkan. Sedangkan, data sekunder berupa karateristik SMAN diperoleh dengan mengumpulkan dan mengoleksi data-data (dokumen) yang berhubungan dengan penelitian yang diperoleh dari sekolah dan Dinas Pendidikan Kota Palangka Raya serta laman http://arsip-arsipppdb.com/kotapalangkaraya.

Analisis tabulasi deskriptif digunakan untuk mengidentifikasi dan menggambarkan keberadaan KMPG di SMAN di Palangka Raya. Data yang sama kemudian dikelompokan dan dipersentasekan. Persentase terbesar merupakan jawaban yang dominan dari masing-masing karakter yang dikumpulkan.

$$
D P=\frac{n}{N} 100 \%
$$

Keterangan:

$D P \quad$ : deskriptif persentase (\%)

$n$ : skor empirik atau skor yang diperoleh

$N \quad$ : Skor ideal/jumlah total nilai

KMPG diklasifikasikan menjadi empat kelas dengan interval kelas sebesar 25\% (Tabel 1). Klasifikasi penentuan kualitas UN SLTP, tingkat persaingan, prestasi akademik di bidang geografi, dan sekolah digunakan pengklasifikasian metode purata (Tabel 2). Penentuan kualitas sekolah didasarkan pada tiga komponen, yaitu: 1) purata nilai UN minimum untuk diterima di SMAN bersangkutan; 2) tingkat persaingan (daya tampung dibagi dengan jumlah peminat; dan 3), prestasi akademik di bidang geografi selama lima tahun terakhir.

Analisis tabulasi silang digunakan untuk menggambarkan kualitas MPG. Tabel silang atau tabulasi silang memperlihatkan hubungan antar dua atau lebih peubah secara bersamaan. Tabel silang memadukan distribusi frekuensi dari dua atau lebih peubah dalam satu tabel (Indratno \& Irwinsyah, 1998; Sumarwan, 2012). Analisis tabulasi silang yang digunakan dalam penelitian ini adalah tabulasi-khi kuadrat untuk menguji hubungan antar peubah data ordinal. Prosedur analisis tabulasi silang merujuk pada Indratno \& Irwinsyah (1998) dan Sumarwan (2012) dengan bantuan perangkat lunak SPSS 18.0 (SPSS, 2009) dengan panduan yang dikembangkan oleh Abdullah \& Sutanto (2015).

\section{Hasil}

Karakteristik sekolah. Delapan SMAN di Kota Palangka Raya memiliki rentang usia berkisar dari 1 - 56 tahun. SMAN 1 merupakan SMA tertua di Kota Palangka Raya sekaligus sekolah terbesar di Kota Palangka Raya (jumlah guru dan jumlah siswa). SMAN-SMAN telah berusia $>20$ tahun memiliki guru $>50$ orang. Sedangkan SMAN 8 adalah SMAN dengan jumlah guru paling sedikit. Adapun jumlah guru mata pelajaran geografi yang memenuhi syarat minimal di sekolah adalah SMAN 1 dan SMAN 3 sedangkan sisanya jumlah gurunya < 3 . Empat SMAN memiliki jumlah siswa hampir 1.000 siswa dan memiliki jurusan yang lengkap. Namun, Ada dua SMAN yang jumlah siswanya $<100$ siswa, yaitu SMAN 8 dan SMAN 10 (Tabel 3).

SMAN di Kota Palangka Raya umumnya memiliki akreditasi yang baik (Gambar 1). 
Bahkan lima SMAN yang ada memiliki peringkat akreditasi yang sangat baik atau A. Kelima SMAN tersebut merupakan SMAN yang telah lama berdiri. Sedangkan, dua SMAN contoh berikutnya memiliki peringkat akreditasi yang baik atau B. Hanya satu SMAN yang belum terakreditasi karena baru dibuka (2014).

Sebagian besar SMAN di Palangka Raya cenderung memiliki kualitas yang kurang bagus. Hanya tiga SMAN yang dikategorikan sebagai sekolah yang berkualitas baik. Ketiga SMAN itu adalah SMAN 1, SMAN 2, dan SMAN 5 (Gambar 2). Sisanya masih perlu ditingkatkan kualitas akademiknya.
KMPG pada SMAN-SMAN di Kota Palangka Raya secara umum menunjukan kriteria kurang lengkap. Hanya ada satu SMAN yang menunjukan KMPG yang bagus. Sisanya KMPG di SMAN negeri kondisi kurang lengkap (Gambar 3). SMAN 2 Palangka Raya merupakan SMAN dengan KMPG yang paling bagus. SMA tersebut memiliki 29 jenis MPG dari 55 total jenis media pembelajaran yang diperlukan untuk mendukung proses belajar mengajar mata pelajaran geografi (Tabel 4). Secara umum video compact disk (VCD) dan perangkat lunak serta peralatan laboratorium merupakan MPG yang jarang dikoleksi oleh SMAN di Kota Palangak Raya.

Tabel 1. Klasifikasi KMPG di SMAN di Palangka Raya.

\begin{tabular}{ccc}
\hline Skor & Persentase $(\%)$ & Kriteria \\
\hline 4 & $76-100$ & Sangat lengkap \\
3 & $51-75$ & Lengkap \\
2 & $26-50$ & Kurang lengkap \\
1 & $0-25$ & Tidak lengkap \\
\hline Sumber: Ali (1993) yang dikutip oleh Awaludin (2007).
\end{tabular}

Tabel 2. Klasifikasi pentuan kualitas sebagai dasar penentuan kualitas sekolah.

\begin{tabular}{ccc}
\hline Skor & Interval & Kriteria \\
\hline 2 & $N \geq \bar{x}+S D$ & Bagus \\
1 & $N<\bar{x}+S D$ & Kurang bagus
\end{tabular}

Sumber: Kuncoro, 2009. $N=$ nilai; $\bar{x}=$ purata; dan $S D=$ simpangan baku.

Tabel 3. Sebaran karakteristik SMAN di Palangka Raya1).

\begin{tabular}{cccccr}
\hline $\begin{array}{c}\text { Nama } \\
\text { SMA }\end{array}$ & Tahun Berdiri & Jumlah Guru & $\begin{array}{c}\text { Jumlah Guru } \\
\text { Geografi }\end{array}$ & $\begin{array}{c}\text { Jumlah } \\
\text { Jurusan }\end{array}$ & Jumlah Siswa $^{2)}$ \\
\hline SMAN 1 & 1959 & 85 & 4 & 3 & 1.259 \\
SMAN 2 & 1983 & 83 & 2 & 3 & 1.023 \\
SMAN 3 & 1986 & 77 & 3 & 3 & 959 \\
SMAN 4 & 1994 & 74 & 2 & 3 & 1.067 \\
SMAN 5 & 1995 & 38 & 1 & 2 & 367 \\
SMAN 6 & 2002 & 33 & 2 & 2 & 292 \\
SMAN 8 & 2010 & 7 & 1 & 2 & 32 \\
SMAN 10 & 2014 & 21 & 1 & 2 & 20 \\
\hline
\end{tabular}


Tabel 4. Sebaran jumlah jenis MPG di SMAN di Palangka Raya.

\begin{tabular}{|c|c|c|c|c|c|c|c|c|c|c|c|}
\hline \multirow{2}{*}{$\begin{array}{l}\text { Nama } \\
\text { Sekolah }\end{array}$} & \multicolumn{10}{|c|}{ Materi ${ }^{1)}$} & \multirow{2}{*}{ Total } \\
\hline & 1 & 2 & 3 & 4 & 5 & 6 & 7 & 8 & 9 & $10^{2)}$ & \\
\hline SMAN 1 & $0(1)$ & $1(5)$ & $3(13)$ & $1(6)$ & $1(3)$ & $2(10)$ & $1(3)$ & $2(4)$ & $2(4)$ & $6(6)$ & $19(55)$ \\
\hline SMAN 2 & $0(1)$ & $1(5)$ & $0(13)$ & $5(6)$ & $3(3)$ & $7(10)$ & $1(3)$ & $2(4)$ & $4(4)$ & $6(6)$ & $29(55)$ \\
\hline SMAN 3 & $0(1)$ & $1(5)$ & $5(13)$ & $4(6)$ & $2(3)$ & $3(10)$ & $1(3)$ & $1(4)$ & $2(4)$ & $4(6)$ & $23(55)$ \\
\hline SMAN 4 & $0(1)$ & $2(5)$ & $5(13)$ & $0(6)$ & $1(3)$ & $1(10)$ & $0(3)$ & $3(4)$ & $3(4)$ & $5(6)$ & $21(55)$ \\
\hline SMAN 5 & $0(1)$ & $2(5)$ & $0(13)$ & $2(6)$ & $1(3)$ & $3(10)$ & $1(3)$ & $2(4)$ & $0(4)$ & $5(6)$ & $16(55)$ \\
\hline SMAN 6 & $0(1)$ & $3(5)$ & $5(13)$ & $1(6)$ & $2(3)$ & $5(10)$ & $1(3)$ & $2(4)$ & $1(4)$ & $5(6)$ & $26(55)$ \\
\hline SMAN 8 & $0(1)$ & $0(5)$ & $5(13)$ & $1(6)$ & $0(3)$ & $0(10)$ & $1(3)$ & $1(4)$ & $1(4)$ & $5(6)$ & $14(55)$ \\
\hline SMAN 10 & $0(1)$ & $0(5)$ & $1(13)$ & $1(6)$ & $1(3)$ & $0(10)$ & $0(3)$ & $0(4)$ & $0(4)$ & $2(6)$ & $5(55)$ \\
\hline
\end{tabular}

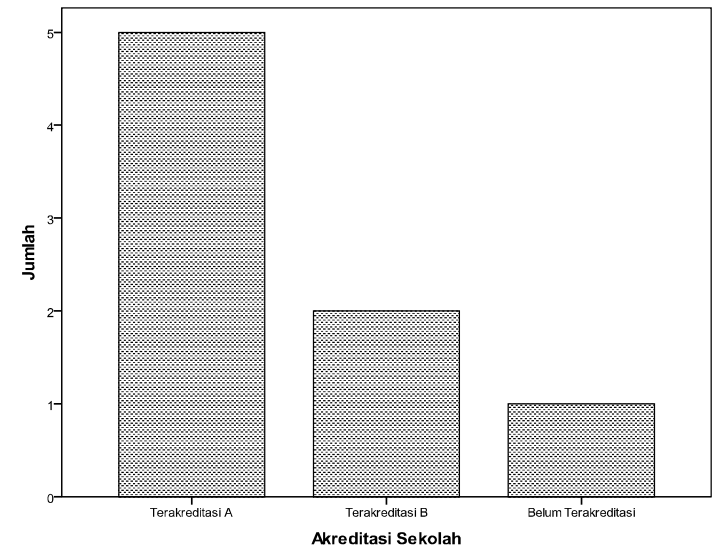

Gambar 1.

Sebaran Peringkat akreditasi SMAN di Palangka Raya.

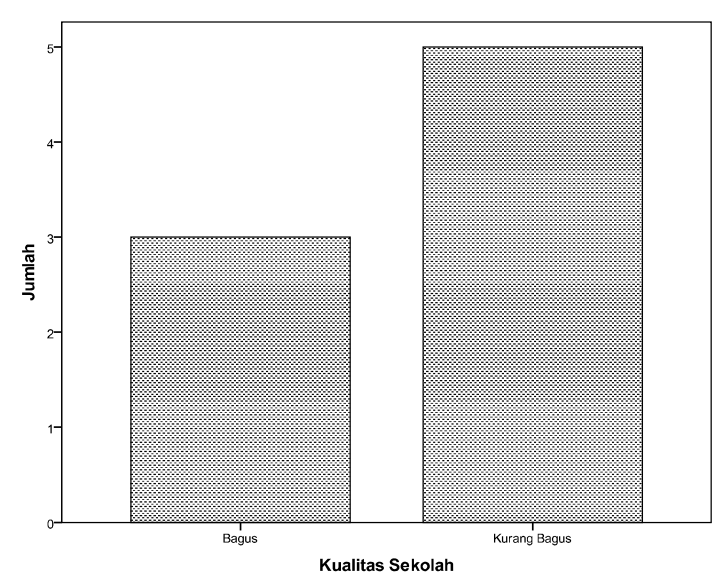

Gambar 2. Sebaran Status Kualitas SMAN di Palangka Raya.

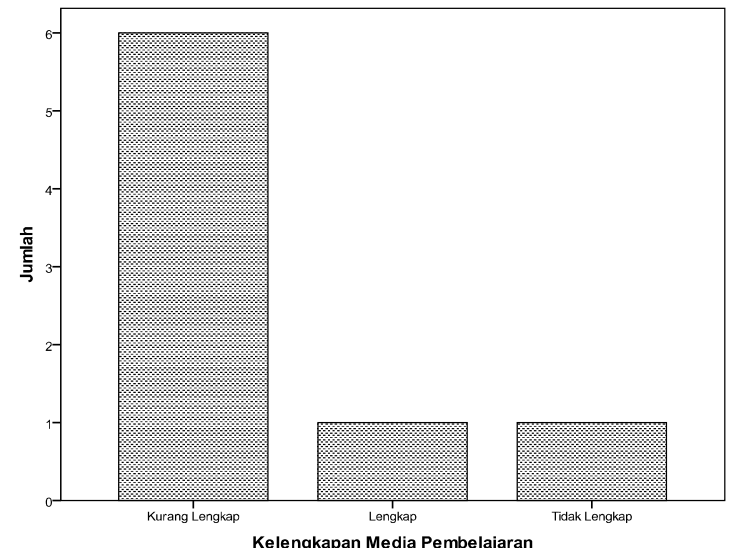

Gambar 3.

Sebaran Status KMPG SMAN di Palangka Raya.

Hubungan antara akreditasi sekolah dengan KMPG. Sekolah yang belum terakreditasi menunjukan KMPG yang sangat rendah (tidak lengkap), sedangkan sekolah yang telah terakreditasi menunjukan KMPG yang lebih bagus. Sekolah yang terakreditasi B sebanyak $100 \%$ yang dikategorikan dalam kurang lengkap kemudian persentasenya menurun menjadi $80 \%$ pada sekolah yang terekreditasi lebih baik. Hal ini menunjukan bahwa semakin tinggi akreditasi sekolah, semakin lengkap KMPG (Tabel 5). Namun, secara statistika hubungan ini tidak nyata $\left(\chi^{2}=8,533 ; d f=\right.$ $4 ; p=0,074)$. Persentase sumbangsih 
akreditasi sekolah terhadap KMPG cukup tinggi meskipun secara statistika tidak bermakna $(C=0,718 ; p=0,074)$.

Ringkasan statistik inferensi hubungan antara akreditasi sekolah dengan KMPG disajikan pada Tabel 6 .

Tabel 5. Tabulasi silang distribusi frekuensi akreditasi sekolah dalam KMPG.

\begin{tabular}{lrrrr}
\hline & \multicolumn{3}{c}{ Akreditasi Sekolah } & \multirow{2}{*}{ Total } \\
\cline { 2 - 4 } & \multicolumn{1}{c}{$\mathrm{BA}$} & \multicolumn{1}{c}{$\mathrm{B}$} & \multicolumn{1}{c}{$\mathrm{A}$} & \\
\hline Tidak lengkap & $1(0,1)$ & $0(0,3)$ & $0(0,6)$ & $1(1,0)$ \\
& $\mathbf{1 0 0} \%$ & $\mathbf{0} \%$ & $\mathbf{0} \%$ & $\mathbf{1 2 , 5} \%$ \\
Kurang lengkap & $0(0,8)$ & $2(1,5)$ & $4(3,8)$ & $6(6,0)$ \\
& $\mathbf{0} \%$ & $\mathbf{1 0 0} \%$ & $\mathbf{8 0} \%$ & $\mathbf{7 5 , 0} \%$ \\
Lengkap & $0(0,1)$ & $0(0,3)$ & $1(0,6)$ & $1(1,0)$ \\
& $\mathbf{0} \%$ & $\mathbf{0} \%$ & $\mathbf{2 0} \%$ & $\mathbf{1 2 . 5} \%$ \\
\hline Jumlah & $1(1,0)$ & $2(2,1)$ & $5(5,0)$ & $8(8,0)$ \\
& $\mathbf{1 0 0} \%$ & $\mathbf{1 0 0} \%$ & $\mathbf{1 0 0} \%$ & $\mathbf{1 0 0} \%$ \\
\hline
\end{tabular}

Keterangan: BA (belum terakreditasi); B (terakreditasi B); A (terakreditasi A). Angka dalam kurung menunjukan nilai harapan. Nilai yang tercetak tebal menunjukan angka persentase yang dihitung dalam kolom.

Tabel 6. Ringkasan analisis khi-kuadrat antara peubah akreditasi sekolah dengan peubah KMPG.

\begin{tabular}{lccc}
\hline & Nilai & $d b$ & $p$ \\
\hline Khi-kuadrat $\left(X^{2}\right)$ & 8,533 & 4 & $0,074^{\text {tn }}$ \\
Koefisien Kontijensi $(C)$ & 0,718 & - & $0,074^{\text {tn }}$ \\
\hline
\end{tabular}

Keterangan: $N=8 ; d b$ (derajat bebas) $=\{(r-1)(c-1)\} ; t n=$ tidak nyata; $\alpha=0,05$.

Hubungan antara kualitas sekolah dengan KMPG. Sekolah dengan kualitas kurang baik menunjukan perbaikan KMPG Sekolah yang berkualitas kurang baik memiliki persentase KMPG sebanyak 25 $\%$ kemudian menurun menjadi $0 \%$ pada pada sekolah dengan kualitas yang baik. Hal ini identik dengan KMPG dalam kategori lengkap juga menunjukan yang sama, dimana sekolah yang makin berkualitas maka KMPG-nya makin bagus. Namun demikian, kecenderungan yang berbeda ditunjukan pada KMPG dalam kategori kurang lengkap. Kualitas sekolah baik tidak menunjukan penurunan kategori kurang lengkap pada KMPG (Tabel 7). Hal ini didukung analisis statistik khi- kuadrat $\left(\chi^{2}=2,000 ; d f=2 ; p=0,368\right)$ yang menyatakan bahwa tidak ada hubungan yang bermakna antara kualitas sekolah dengan KMPG (Tabel 8). Kekuatan hubungan kedua peubah juga tidak kuat $C<0,600$ bahkan tidak nyata ( $p$ $=0,368$ ).

Tabel 7. Tabulasi silang distribusi frekuensi kualitas sekolah dalam KMPG.

\begin{tabular}{lccc}
\hline \multirow{2}{*}{ KMPG } & \multicolumn{2}{c}{ Kualitas Sekolah } & Total \\
\cline { 2 - 3 } & $\mathrm{KB}$ & $\mathrm{B}$ & $\mathbf{1}(1,0)$ \\
Tidak lengkap & $1(0,5)$ & $0(0,5)$ & $\mathbf{1 2 , 5} \%$ \\
& $\mathbf{2 5 , 0} \%$ & $\mathbf{0 , 0} \%$ & $6(6,0)$ \\
Kurang lengkap & $3(3,0)$ & $3(3,0)$ & $\mathbf{7 5 , 0} \%$ \\
& $\mathbf{7 5 , 0} \%$ & $\mathbf{7 5 , 0} \%$ & $1(1,0)$ \\
Lengkap & $0(0,5)$ & $1(0,5)$ & $\mathbf{1 2 , 5} \%$ \\
\hline Jumlah contoh & $\mathbf{0 , 0} \%$ & $\mathbf{2 5 , 0} \%$ & $\mathbf{8}(8,0)$ \\
& $4(4,0)$ & $\mathbf{4}(4,0)$ & $\mathbf{1 0 0 , 0} \%$ \\
\hline
\end{tabular}

Keterangan: KB (kurang bagus); B (bagus). Angka dalam kurung menunjukan nilai harapan. Persentase dihitung dalam kolom. 
Tabel 8. Ringkasan analisis khi-kuadrat antara peubah kualitas sekolah dengan peubah KMPG.

\begin{tabular}{lccc}
\hline & Nilai & $d b$ & $p$ \\
\hline $\begin{array}{l}\text { Khi-kuadrat }\left(x^{2}\right) \\
\text { Koefisien }\end{array}$ & 2,000 & 2 & $0,368^{\text {tn }}$ \\
Kontijensi $(C)$ & 0,447 & - & $0,368^{\text {tn }}$ \\
\hline
\end{tabular}

Keterangan: $N=8 ; d b$ (derajat bebas) $=\{(r-1)(c-1)\} ; t n=$ tidak nyata; $\alpha=0,05$.

\section{Pembahasan}

\section{Kelengkapan media pembelajaran}

geografi. Hasil penelitian ini menunjukan bahwa mayoritas SMAN di Kota Palangka Raya belum memiliki MPG yang memadai (Gambar 3). Hasil penelitian ini menunjukan hasil yang tidak berbeda dengan penelitian yang dilakukan oleh Awaludin (2007) dimana dari $>50 \%$ SMAN di Banjarnegara yang disigi menunjukan MPG yang dimiliki dalam kategori kurang lengkap. Namun, hasil ini berbeda dengan sigi yang dilakukan oleh Setianingsih et al. (2013) di Klaten. Mayoritas SMAN di Klaten memiliki MPG yang lengkap. Perbedaan hasil penelitian ini diduga disebabkan oleh perbedaan kriteria MPG yang digunakan dalam penelitian masingmasing. Penelitian ini sejalan dengan Awaludin (2007) yang menekankan keberadaan MPG yang mendukung materi pembelajaran geografi di sekolah. Adapun Setianingsih et al. (2013) menitikberatkan klasifikasi kelengkapan media berdasarkan jenis medianya (persepsi panca indera).

Media pembelajaran secara umum diklasifikasi menjadi tiga kelompok, yaitu: 1) persepsi panca indera: media audio, media visual, dan media audio-visual; 2) sasaran pengguna: individu, kelompok kecil, dan massal; dan 3) cara penggunaan: konvensional/sederhana dan mutahir/kompleks (Prasetya, 2014).

Secara umum, MPG berupa VCD atau perangkat lunak, peralatan laboratorium, maket, dan peraga serta spesimen belum dimiliki oleh SMAN-SMAN di Kota Palangka Raya. Media-media tersebut harus diadakan secara khusus dengan melakukan pemesanan kepada lembaga penyedia media pembelajaran dan peralatan laboratorium. Media-media ini tidak tersedia bebas di pasaran. Sehingga pihak sekolah ataupun guru-guru geografi tidak menyediakannya. Sedangkan, MPG utama seperti globe, peta dan atlas sudah dimiliki. Ketiga MPG tersebut harus dimiliki sehingga pihak sekolah mengalokasikan dana untuk mengadakan media-media tersebut. Akan tetapi jumlah media tersebut jumlahnya tidak sesuai dengan kebutuhan.

Di samping itu, media pembelajaran pendukung seperti proyektor, laptop, ruang komputer, perpustakaan, dan buku pendukung pembelajaran geografi secara umum tersedia dengan baik. Media-media ini memiliki penggunaan yang umum dan mudah digunakan. Sehingga keempat media tersebut tersedia di sekolah, akan tetapi jumlahnya belum memadai. Akan tetapi, SMAN 10 belum memiliki perpustakaan dan proyektor. SMANSMAN dengan kategori baik memiliki media tersebut dengan jumlah yang relatif memadai.

Media-media tersimpan di perpustakaan ataupun di ruang guru. Tidak ada ruang khusus (laboratorium geografi) yang digunakan untuk menyimpan media pembelajaran yang ada. Selain itu, inventarisasi dan manajemen media pembelajaran belum tertata dengan baik. Hal ini terkait dengan perencaaan dan pendanaan sekolah. Guru-guru senior biasanya memiliki literasi teknologi yang rendah sehingga mereka jarang menggunakan MPG yang berbasis teknologi informatika. Guru-guru yang berasal dari lulusan pendidikan geografi lama (sebelum tahun 2000) dan tidak 
memperbaharui kompetensinya umumnya mengalami kesulitan memahami materimateri pelajaran geografi terkini (Prismanata, 2013). Kedua hal tersebut merupakan hambatan pengadaan MPG pada SMAN-SMAN di Kota Palangka Raya.

Pembangunan laboratorium geografi belum menjadi prioritas utama sekolah. Berbeda dengan laboratorium MIPA ataupun laboratorium bahasa yang sudah menjadi prioritas pembangunan di SMA. Laboratorium geografi dapat digunakan oleh siswa ataupun guru dalam rangka peningkatan kualitas pembelajaran geografi. Selain itu, laboratorium geografi juga dapat digunakan sebagai tempat penyimpanan MPG yang dimiliki oleh sekolahan. Materi-materi geografi yang bersifat abstrak, teknis, dan padat subtansi (seperti: konsep \& aspek geografi, geosfera, biosfera, antrosfera, pemetaan, penginderaan jauh \& sistem informasi geografi; dan wilayah \& perwilayahan) perlu diimbangi dengan keberadaan media pembelajaran dan laboratorium (Prismanata, 2013). Secara umum kendala-kendala yang dihadapi dalam pengadaan media pembelajaran di sekolah, antara lain: dana dan keberadaan ruangan khusus untuk menyimpan media pembelajaran (Awaludin, 2007; Prismanata, 2013; Setianingsih et al., 2013) akses terbuka terhadap media, perawatan media, tenaga khusus yang mengelola media pembelajaran, dan literasi teknologi yang dimiliki oleh guru (Setianingsih et al., 2013). Padahal pemanfaatan media pembelajaran berbasis teknologi informasi dapat menggantikan dan mengatasi permasalahan keterbatasan MPG konvensional (Suprapto, 2006).

Media pembelajaran memiliki jenis dan bentuk yang beragam. Tidak semua media pembelajaran digunakan secara bersama dan serentak dalam proses belajar mengajar. Perlu dipilih media pembelajarn geografi yang paling tepat untuk meningkatkan kualitas pembelajaran. Metode ASSURE dapat diterapkan dalam pemilihan MPG. Metode ini menekankan pada perencanaan penggunaan media pembelajaran. Tahapan metode ASSURE terdiri dari: 1) Analysis learner (analisis karakteristik siswa); 2) State objectives (tetapkan tujuan pembelajaran); 3) Select methods, media and materials (pemilihan metode, media dan bahan pelajaran); 4) Require learner participants (menyiapkan partisipasi siswa); dan 5) Evalute \& review (mengadakan evaluasi dan ulas balik) (Prasetya, 2014).

Faktor-faktor yang harus dipertimbangkan oleh pengajar dalam penggunaan media pembelajaran antara lain: 1) tidak ada satu media yang paling unggul untuk semua tujuan; 2) media merupakan bagaian yang tak terpisahkan dalam proses belajar-mengajar; 3) sasaran utama penggunaan media adalah memudahkan proses pembelajaran; 4) penggunaan media bukan sekedar pengisi waktu atau hiburan; 5) pemilihan media harus obyektif; 6) penggunaan media secara serentak dapat membingungkan peserta belajar; dan 7) kebaikan dan keburukan media tidak tergantung pada kekongkritan dan keabsatrkannya (Prasetya, 2014).

$\begin{array}{llr}\text { Faktor-faktor } & \text { yang } & \text { mempengaruhi } \\ \text { kelengkapan } & \text { media } & \text { pembelajaran }\end{array}$ geografi. Akreditasi sekolah tidak berhubungan langsung dengan KMPG $\left(\chi^{2}\right.$ $=8,533 ; d b=4 ; C=0,718 ; p=0,074)$, begitu juga dengan kualitas sekolah $\left(\chi^{2}=\right.$ $2,000 ; d b=2 ; \quad C=0,447 ; p=0,368)$. Pengadaan media pembelajaran pendukung proses belajar mengajar di sekolah umumnya ditentukan oleh skala prioritas yang ditentukan oleh sekolah masing-masing.

Hubungan yang tidak nyata antara akreditasi sekolah dan kualitas sekolah 
dengan KMPG dipengaruhi oleh beberapa hal, yaitu: Pertama. Penilaian akreditasi sekolah pembobotan utamanya pada aspek sumberdaya manusia dan iklim sekolah. Sedangkan aspek fasilitas dan pemanfaatannya memiliki proporsi yang kecil. Sumarno \& Kholis (2002) menjelaskan pembobotan aspek penilaian akreditasi sekolah sebagai berikut: sumberdaya manusia (25\%), iklim sekolah $(25 \%)$, arus siswa (20\%), fasilitas dan pemanfaatannya dan orang tua siswa dan masyarakat masing-masing (15\%). Sehingga kelengkapan media pembelajaran bukan faktor utama penilaian akreditasi. Meskipun demikian, kecenderungan secara umum sekolah yang memiliki akreditasi ataupun kualitas yang baik memiliki kelengkapan media pembelajaran yang lebih baik dibandingkan sekolah dengan akreditasi ataupun kualitas yang lebih rendah. Sekolah yang berkualitas umumnya berkorelasi dengan tingkat akreditasi sekolah. Hasil akreditasi merupakan bukti kualitas sekolah (Sumintono, 2013).

Kedua. Pembiayaan sekolah. Sekolah yang berkualitas/terakreditasi baik memiliki potensi dana pengembangan yang besar yang berasal dari masyarakat. Sumber dana yang besar memungkinkan sekolah untuk membelanjakan dana untuk peningkatan kualitas sekolah. Sumintono (2013) menjelaskan program pembangunan sarana dan prasarana, budaya sekolah, kegiatan kesiswaan memerlukan dukungan dana untuk melaksanakannya. Namun demikian, manajemen pendidikan berbasis sekolah yang berkembang sekarang memberikan kesempatan kepada sekolah untuk mengembangkan dan melaksanakan pendidikan secara otonom. Sekolah dapat menyusun program perbaikan kualitas pendidikan di tingkat sekolah (Sumarno \& Kholis, 2002).

Perbaikan kualitas yang dilakukan oleh sekolah ditandai dengan peningkatan kualitas sumberdaya manusia, penambahan fasilitas sekolah, dan perbaikan pelayanan. Penambahan fasilitas umumnya dilakukan dengan pembangunan sarana seperti perpustakaan, ruang multimedia atau komputer, laboratorium IPA, dan laboratorium bahasa, serta media pembelajar pendukung seperti proyektor, komputer, dan buku-buku pelajaran. Hal ini sesui dengan pendapat Yudi (2012) yang menyatakan bahwa kebijakan peningkatan kualitas sekolah diutamakan untuk membantu peserta didik berkembang secara optimal dengan cara: 1) menyediakan fasilitas yang mendukung peserta didik belajar, seperti fasilitas olahraga, ruang bermain, dan ruang guru yang memadai; 2) memperkaya media pembelajaran; serta 3) membangun perpustakaan dan laboratorium. Lebih lanjut, fasilitas dan sarana pembelajaran yang kurang memadai dapat menurunkan kualitas pembelajaran sekolah (Suprapto, 2006).

Namun, demikian pembangunan laboratorium geografi belum menjadi prioritas. Hal ini diduga terkait juga dengan faktor ketiga, yaitu kepala sekolah. Kepala sekolah memiliki peranan penting dalam penentuan kebijakan dan kemajuan sekolah. Kepala sekolah bertanggung jawab untuk mempengaruhi seluruh pemangku kepentingan sekolah untuk meningkatkan kualitas pembelajaran (Triyanto, Anitah, \& Suryani, 2013). Kepala sekolah dapat memberikan motivasi kepada guru untuk menggunakan dan melengkapi media pembelajaran. Sistem merit yang diterapkan oleh kepala dapat digunakan untuk meningkatkan pemanfaatan media pembelajaran.

Faktor keempat adalah guru. Proses belajar mengajar di kelas dikelola oleh guru. Guru yang kompeten memiliki pengetahuan dan keterampilan untuk mengelola kelas dengan baik sehingga proses pembelajaran berjalan efektif dan 
tujuan pembelajaran tercapai.

Pemberdayaan media pembelajaran di sekolah berhubungan dengan pengetahuan dan keterampilan guru (Triyanto et al., 2013).

Namun demikian, kualitas sekolah bukan hanya dipengaruhi oleh kekayaan ataupun kelengkapan media pembelajaran. Ada beberapa faktor yang mempengaruhinya, seperti: kualitas perilaku pembelajaran guru, kualitas perilaku belajar siswa, iklim pembelajaran, materi pembelajaran, dan sistem pendidikan (Depdiknas, 2005 yang dikutip oleh Rohman, 2010); saranaprasarana sekolah dan lingkungan (KaroKaro, 2013); manajemen sekolah, pembiayaan pendidikan dan kepemimpinan (Sumintono, 2013; Yudi, 2012); serta kurikulum dan proses belajar mengajar (Yudi, 2012).

Media pembelajaran sebagai salah satu komponen penting dalam penentu kualitas sekolah maka pengadaan media pembelajaran harus dilakukan dengan baik. Pengadaan media pembelajaran harus mempertimbangkan beberapa aspek, antara lain: 1) akses, biaya, teknologi, interaktif, organisasi dan keterbaruan (Sanjaya, 2011); 2) relevansi pengadaan media, kelayakan pengadaan media, dan kemudahan pengadaan media (Prasetya, 2014; Rohani, 1997); 3) ketersediaan sumber setempat, dana, tenaga dan fasilitas, keluwesan, kepraktisan, serta ketahanan media, efektivitas dan efisiesi biaya (Prasetya, 2014).

Implikasi dan Keterbatasan penelitian. Sekolah perlu mengadakan inventarisasi keberadaan media pembelajaran yang digunakan untuk mendukung proses belajar mengajar dan membangun ruangan khusus untuk menyimpan media pembelajaran yang ada. Setelah itu dilakukan penetapan skala prioritas pengadaan media pembelajaran, bukan hanya untuk mata pelajaran geografi tetapi juga mata pelajaran yang lain. Guruguru dapat mengoptimalkan dan memberdayakan media pembelajaran yang ada untuk mendukung prose belajar mengajar dengan meningkatkan kemampuan dan literasi teknologi. Kualitas manajemen sekolah perlu ditingkatkan dengan mendata dan mengadministrasikan data sekolah dengan baik dan benar sehingga sekolah dapat melakukan evaluasi dan masyarakat dapat mengakses data tersebut.

Penelitian ini memiliki keterbatasan yang disebabkan oleh beberapa faktor, antara lain: 1) koleksi data yang dimiliki oleh sekolah ataupun instansi terkait untuk mendukung penelitian ini kurang memadai. Data terkait karakteristik sekolah sebagai dasar penentuan kualitas sekolah tidak terdata dengan baik sehingga penulis menggunakan data sekunder yang kurang faktual dan rinci (arsip-arsip-ppdb.com/kotapalangkaraya); 2) meskipun hampir keseluruhan SMAN di Kota Palangka Raya sudah disigi tetapi masih ada dua sekolah yang belum di sigi karena keterbatasan waktu, biaya dan tenaga. SMAN 7 dan SMAN 9 memiliki aksesibilitas yang sulit (jalur sungai dan jauh) serta berada di luar Kota Palangka Raya; 3) angket yang dijawab dengan tidak lengkap oleh responden. Namun dalam penelitian ini tanggapan responden tetap diperhatikan dan dianalisis dalam penelitian ini.

\section{Kesimpulan}

KMPG di SMAN-SMAN di Kota Palangka Raya menunjukan kondisi yang kurang memadai (kurang lengkap). Hanya ada satu SMAN negeri yang memiliki KMPG dengan kategori baik dari total delapan SMAN yang disigi. SMAN yang lain hanya memiliki jumlah (jenis) MPG $<50 \%(9-47 \%)$. Status akreditasi sekolah dan kualitas sekolah tidak menunjukan korelasi yang nyata dengan KMPG pada 
SMAN yang disigi. Namun demikian ada kecenderungan dimana sekolah dengan akreditasi yang baik memiliki KMPG yang lebih bagus.

Penelitian ke depan perlu dikembangkan angket yang lebih sederhana dan dalam proses pengisian perlu pendampingan selama proses pengisiaan. Angket yang digunakan dalam penelitian hanya mengekplorasi keberadaan media pembelajaran (jumlah dan jenis media). Ekplorasi tentang pemanfaatan, kendala-kendala dan penanggungjawab media pembelajaran (khususnya geografi) belum terungkap dalam penelitian ini.

\section{Daftar Pustaka}

Abdullah, S., \& Sutanto, T. E. (2015). Statistika Tanpa Stress. Jakarta: Transmedia.

Awaludin, M. (2007). Survei Sarana Dan Prasarana Pembelajaran Mata Pelajaran Geografi SMA Negeri Di Kabupaten Banjarnegara Tahun Ajaran 2006/2007. Universitas Negeri Semarang.

Inc, S. (2009). PASW Statistics for Windows, Version 18.0. Chicago: SPSS Inc.

Indratno, I., \& Irwinsyah, R. (1998). Aplikasi Analisis Tabulasi Silang (Crosstab) Dalam Perencanaan Wilayah Dan Kota. JPWK, 9, 48-59.

Karo-Karo, D. (2013). Meningkatkan Kualitas Layanan Belajar Untuk Mengimplementasikan Kurikulum 2013 Dengan Menggunakan Media Pembelajaran. Jurnal Handayani, 1(2), 40-52.

Prasetya, S. M. (2014). Media Pembelajaran Geografi. Yogyakarta: Penerbit Ombak.

Prismanata, Y. (2013). Pemetaan Penguasaan Materi Geografi Pada Peserta Didik SMA Berdasarkan Nilai Ujian Nasional Menurut Status Sekolah Dan Kategori Akreditasi Di Surakarta Tahun 2010-2012. Universitas Negeri Surakarta.

Rohani, A. (1997). Menakar Potret Realitas Dan Idealitas Kualitas
Sekolah. Jakarta: Rineka Cipta.

Rohman, A. (2010). Menakar Potret Realitas Dan Idealitas Kualitas Sekolah. Fondasia, 2(10), 1-15.

Sanjaya, W. (2011). Perencanaan Dan Desain Sistem Pembelajaran. Jakarta: Predana Media.

Setianingsih, S. W., Banowati, E., \& Santoso, A. B. (2013). Ketepatan Pemilihan Dan Penggunaan Media Pembelajaran Geografi SMA Negeri Di Kabupaten Jepara. Edu Geography, 1(2), 57-62.

Shofifah, A., \& Sigit, B. (2013). Pengembangan Media Kartu Hidrologi Untuk Mata Pelajaran Geografi Pada Pokok Bahasan Hidrosfer Dan Dampaknya Terhadap Kehidupan Di Muka Bumi Kelas X SMA Negeri 1 Driyorejo, Gresik. Swara Bumi, 2(3), 195-202.

Siagian, S., \& Lingin. (2012). Pengembangan Media Pembelajaran Interaktif Pada Mata Pelajaran Geografi. Jurnal Teknologi Pendidikan, 5(1), 22-30.

Sidi, P., \& Sudrajat, A. (2014). Pembelajaran Model STS Berbantuan Media Untuk Meningkatkan Aktivitas, Sikap, Dan Hasil Belajar IPS. Harmoni Sosial, 1(2), 179-189.

Sufia, R., \& Kurniawati, A. (2013). Pengaruh Penggunaan Media EBook Dengan Textbook Terhadap Hasil Belajar Pada Materi Biosfer Kelas XI Di SMA Negeri 1 Muncar. Swara Bhumi, 2(1), 142-150.

Sumarno, \& Kholis, N. (2002). Pengembangan Model Akreditasi Sekolah Tingkat SLTP Dan SMU. Jurnal Kependidikan, 32(2), 249-268.

Sumarwan, U. (2012). Analisis Sikap Konsumen Dengan Statistik Uji K Contoh Bebas. (U. Sumarwan, Ed.) (Riset Pema). Bogor: IPB Press.

Sumintono, B. (2013). Sekolah Unggulan: Pendekatan Kapasitas Sekolah. Jurnal Manajemen Pendidikan, 2(1), 1-19.

Suprapto. (2006). Peningkatan Kualitas Pendidikan Melalui Media Pembelajaran Menggunakan Teknologi Informasi Di Sekolah. Jurnal Ekonomi Dan Pendidikan, 
3(1), 34-41.

Triyanto, E., Anitah, A., \& Suryani, N. (2013). Peran Kepemimpinan Kepala Sekolah Dalam Pemanfaatan Media Pembelajaran Sebagai Upaya Peningkatan Kualitas Proses Pembelajaran. Jurnal Teknologi Pendidikan, 1(2), 226-238.

Wahyudin, Sutikno, \& Isa, A. (2010). Keefektifan

Berbantuan Pembelajaran Menggunakan Metode Inkuiri Terbimbing Untuk Meningkatkan Minat Dan Pemahaman Siswa. Jurnal Pendidikan Fisika Indonesia, 6(1), 58-62.

Yudi, A. A. (2012). Pengembangan Mutu Pendidikan Ditinjau Dari Segi Sarana Dan Prasarana (Sarana Dan Prasarana PPLP). Cerdas Sifa, 1(1), 1-9. 